\title{
The Effect of Spiritual Intelligence on Employees' Empowerment at Pt.Centra Multi Karya
}

\author{
Lita Wulantika \\ Doctoral Student of Management Science, Padjadjaran University, Bandung, Indonesia and Lecturer of Economics Faculty \\ Indonesian Computer University, Bandung, Indonesia; litabelva@gmail.com
}

\section{Refi Mayasari Buhari}

Master Student of Management Education, Economics Faculty of Open University, Bandung Indonesia endo.refi@gmail.com

\section{Doi:10.5901/mjss.2015.v6n5s5p151}

\section{Abstract}

This study was conducted to analyze: 1) The effect of spiritual intelligence on employee performance, 2) The effect of employee empowerment on employee performance, and 3) The effect of spiritual intelligence and employee empowerment on employee performance at PT. CMK. The hypothesis in this study was 1) Spiritual intelligence affects the employee performance. 2) Employee empowerment affects the employee performance. 3) Spiritual intelligence and employee empowerment affect the employee performance. This study was conducted to analyze: 1) The effect of spiritual intelligence on employees' performance, 2) the effect of employees' empowerment on employees' performance, and 3) The effect of spiritual intelligence and employees' empowerment on employees' performance at PT. CMK. The hypothesis in this study are 1)Spiritual intelligence affects the employees' performance, 2) Employees' empowerment affects the employees' performance, 3) Spiritual intelligence and employees' empowerment affects the employees' performance. The statistic method which is used in this study is inferential statistic, and the type of study is descriptive verification study. The sample was the employees at PT CMK of 57 respondents from 102 populations. The data of spiritual intelligence, employees' empowerment and employees' performance used questionnaire method and Likert scale. The data analysis used statistical multiple regression analysis. The descriptive result showed in general that spiritual intelligence and employees' empowerment at PT CMK is in the high category. According to hypothetical testing, it is assumed that spiritual intelligence and employees' empowerment affect significantly on employees' empowerment. This study is expected to widen perception and enrich knowledge for academics about spiritual intelligence, employees' empowerment, and employees' performance, as for practitioners, it is expected to be beneficial in enriching references that can help to implement spiritual intelligence, employees' empowerment, and employees' performance.

Keywords: Spiritual Intelligence, Employee Empowerment and Employee Performance

\section{Introduction}

Human is given potential by God to use it in managing the earth so that it provides happiness for the man himself. Earth which has abundant natural resources requires human to be capable in expressing immediately all of his potentials.

Human expression will appear when he can enjoy and interpret any work that he does and can synchronize between emotions, feelings and brain. Spiritual intelligence teaches people to express and give meaning to every action, thus if they want to show good performances, spiritual intelligence is needed (Munir, 2000).

Amaram (2005) states that spiritual intelligence involves a sense of meaning and has a mission in life "the meaning in the sense of life sanctity", a balanced understanding of the material value, and hopes a better world. This opinion is reinforced by research of Wiersma (2002), his research result states that a person who carries the meaning of spirituality in his work will feel that his life and work are more meaningful. It is not much different from the result of research that is carried out by Biberman and Whittey (1997), who suggest a relation between spiritual intelligence and work, and state that spiritual intelligence influences on a person's behavior in the work.

Spiritual intelligence is the basis of personal belief and the role played by the belief in the reaction by a person and forms life (Esmaiil,2014). Vegan (2003) states that spiritual intelligence make clear mind, connect the mind to the existence, and help the individual to distinguish reality from hallucination. This concept is called love, wisdom, and serves in different cultures.

Spiritual intelligence can be developed by anyone, and intelligence which is possessed by each person must be 
very different, it depends on how the person can make sense of life. Hoffman (2002) states that they who are able to give meaning to their lives and bring spirituality into their work environment will make them better persons so that the performances which are resulted are also better than those who have less spiritual intelligence.

Zohar and Marshall (2000) emphasizes the spiritual intelligence, thinks of it as a human mental talents which are applied to regulate relevant issues to the spirit and values, and in this way we can put him in the state of vast, blooming and meaningful. Wigzorth (2004; cited in Sohrabi, 2007) knows that spiritual intelligence as the ability to conduct with kindness and wisdom that is accompanied by internal and external peace without considering the situation. Spiritual intelligence is applied to solve the problems and issues that are relevant to the meaning of life and values. (Zohar \& Marshall, 2000; Wellman, 2000; Nussle, 2004; King 2007). Spiritual intelligence is the foundation for achieving the meaning of life. The meaning of life includes three aspects, they are it has a goal, is valuable, and it is the efficacy of live according to philosopher. Zohar and Marshall (2000) states that when spiritual intelligence is high, we are looked intellectual and have appropriate behavior. But when the spiritual intelligence is low, people would appear to have behavioral problems. Furthermore, Zohar and Marshall (2004) believe, spiritual intelligence must be grown and developed with the training.

In the workplace, spiritual intelligence helps employees in the context of relationships and aligning personal values with clear objectives which indicates a high level of integrity in the work (Tee et al. 2011). Spiritual intelligence is applied when employees want to use the spiritual capacity and resources for taking critical decision and reasoning in entity issues or the effort to solve daily problems (Emmons, 2000; Zohar \& Marshall, 2000).

Zohar and Marshall (2000) Spiritual intelligence is supreme intelligence that indicates significant and valuable problems in solving relevant problems. Decision-making is very important in an organization, especially in the activities of employees empowerment, it means that decisions which are taken by an employee on the power to take decisions to make them more cautious in making a decision. Vegan (2003) states that spiritual intelligence make clear mind, connect the mind to the existence, and help the individual to distinguish reality from hallucination.

Based on the research result Esmaiil (2014) states that for the success of empowering employees it is necessary to record employees who have intelligence spiritual. Because employees who have high spiritual intelligence have high level of awareness in the work and work full of devotion and responsibility. This mental and behavioral is required by a company to support the success of employee empowerent.

Empowerment is a means of building trust between employees and management. There are two characteristics of empowerment that employees are encouraged to use their own initiative, and employees are not only just authorized, but are also given the resources to make decisions based on their creativity and innovation.

Thomas and Veltahouse (1990) argue that empowerment is a multifaceted thing which the essence can not be encompassed in a single concept. In other words, empowerment implies the need for flexibility to individuals to take action and also to be responsible for his actions according to the task in hand.

In addition to a good empowerment is perceived by employees that management provides more opportunities for employees to develop their creativity, flexibility and autonomy over their own work.

Empowerment is a program or tool which is very good because of the changes in the organization, and the participation of members. But management must also understand that achieving the empowerment level is a long-term initiative and requires continuous management commitment. There was also a good empowerment which is perceived by employees that management provides more opportunities for employees to develop the creativity, flexibility and autonomy over their own work. It is believed that it will bring beneficial effects on employee recognition.

Empowerment is one way that can be used by organizations to make the changes which are needed in order to excel and be able to survive in the increasingly tight competition. Further Nilmawati (2003) argues through empowerment we will understand why and what is happening in the organization, because employees are more involved in decision making and given enough authority and responsibility in completing members tasks.

PT.Centra Multi Karya is an engineering company specializing in the design and manufacturing process equipment which is used primarily for environmental management such as incinerators and filter press. It is certainly included into a profitable business organization. Currently, PT.CMK has about 130 staffs. Not different from other companies, PT.CMK also considers spiritual intelligence is important in supporting the activities of an employee. In general, spiritual intelligence that is owned by employees is still not optimal, we can see that there are still less employees who bring the spiritual aspect in solving problems related to work. If it draws on research by Esmaiil (2014) which states that spiritual intelligence may have an impact on development activities, this condition can also occur in empowerment activities at PT.CMK. Empowerment which has been done by PT.CMK regards sufficient in consideration because the company does still not fully involve the ideas and opinions of employees in the company decision.

This study was conducted to determine how spiritual intelligence of employees and employee empowerment are 
conducted by PT.CMK. In addition to determine the influence of spiritual intelligence on employee empowerment which is done by PT.CMK.

\section{Literature and Hypotheses}

\subsection{Spiritual Intelligence}

Spiritual intelligence is the latest scientific finding which was first initiated by Zohar and Marshall (Agustian, 2003). Spiritual intelligence is able to integrate two other capabilities that have previously been mentioned, namely IQ and EQ (Idrus, 2002, p.57). The centrality of spiritual intelligence on the lives of individuals was also expressed in the conception of Dantley and Rogers (2001) that saw spiritual intelligence as the root of thought, which precedes each set received, structure, or categories of thought.

Zohar and Marshall (2001: 37) defines spiritual intelligence as moral sense, the ability to customize the rigid rules followed by understanding and love as well as the equal ability to see when love and understanding to their limit, it also allows us to grapple with the good and the evil things, to imagine that has not happened, and to lift us out of humility. Eckersley (2000: 5) gives another sense of Spiritual Intelligence. Spiritual Intelligence is defined as a deep intuition feeling to the connectedness with the wide world in our lives.

Dolman (2001) states that spiritual intelligence is the man ability to ask about the meaning of life and experience simultaneously linked and connected between each person and the world that is inhabited. Meanwhile, according Amaram (2007), spiritual intelligence is a set of ability to work and the tool of resources, values, and spiritual features to improve daily life.

Selman, Selman, Selman and Selman (2005) spiritual intelligence refers to the ability to solve problems by using multi-sensory approach.

Nobel (2001) and Vaughan (2003) believe that the eight components that show the development of spiritual intelligence to precision, openness, integrity, humility, kindness, generosity, tolerance and resilience, and the desire to meet other needs (Nazel, 2004). McMullen (2003) believe that values such as courage, integrity, intuition, and compassion are the components of spiritual intelligence.

Wigglesworth (2004) states that spiritual intelligence is the ability to behave with compassion and wisdom, keeping the peace in and out regardless of the circumstances. This opinion is supported by the statement of Zohar and Marshall $(2001,23)$ says that spiritual intelligences is able to make a complete man intellectually, emotionally and spiritually. It is as well as written by Mudali $(2002$, p.3) that being smart is not only expressed by having high IQ, but to be truly smart person, someone must have spiritual intelligence (SQ).

Spiritual intelligence shows a series of capability, capacity, and spiritual resources that the applications in everyday life can lead to adaptation of a person's life. Among the existing definitions of spiritual intelligence, its role in solving the entities problem and find meaning and purpose in action and life events have been emphasized specifically.

Unlike the logical intelligence that a computer has and it is unlike the emotional intelligence that Primate possesses, spiritual intelligence is dedicated to the man who is the most basic kind and the most important intelligence (Kadkhoda 2010, p.6).

\subsection{Empowerment}

The history of the first definition refers to empowerment in 1788 that empowerment is considered as delegation of power within the organization and the role of these forces have been donated or seen in the role of one's organization. Empowerment means a person's enthusiasm to accept the word which is interpreted for the first time as a liability. Empowerment means to make people able to perform the task. (Esmaiil, 2014)

Nilmawati (2003) states that empowerment is giving the responsibility and authority to the employee, the employee involvement in decision making, the conditions of mutual trust between management and employees, the sharing of information, knowledge and commitment that comes from employees themselves to assume responsibility on working.

Straub (1989; in Sadarusman, 2004), defines empowerment as the granting of autonomy, authority, trust, and encouraging individuals within an organization to develop regulations in order to complete the work. Administrative of Khan (1997) offers an empowerment model that can be developed within an organization to ensure the success of the empowerment process in an organization.

Empowerment is putting workers to be responsible for what they do. Thus, managers learn to stop controlling and workers learn together how to take responsibility for their work and make decisions appropriately (Robbins, 2006). 
Meanwhile, according to Khan (2007) describes empowerment is an ongoing interpersonal relationships to build trust between employees and management.

According to Row Brown (2004), empowerment is closely connected with the professionalism that was always originally owned by the individual.

Empowerment (empowerment) is authorized to make decisions in a particular area of operations without having to obtain the approval of others (Luthans, 1998).

Work empowerment is a process of enabling employee and delegating authority in a work environment to make easier for workers to work and have a personal action and behavior that is resulted in positive contribution for the organization mission. Work empowerment dimension is based on the concept of Kanter $(1977,1993)$ includes information access (information), resources access (resources), support access (support) and opportunities access (opportunity).

Kanter $(1997,1993)$ and has been adopted by Kulusta, et el. (2004) work empowerment is a process of enabling and delegating of authority in a working environment to make easier for workers to work and have a personal action and behavior that resulted in a positive contribution to the organization mission. Romie Littrell F. (2006), supports this research, that the effective empowerment is when managers do good management and workers do good as well.

Empowerment is a management approach that allows employees to make their own decisions (Robins \& Culter, 1996, p. 34). In other words, empowerment is delegation of power to non-managers for making organization important decision. (Esmaiil, 2014)

Empowerment is giving decision-making power to the employees in order to increase their success and play a useful role in the organization (Arstad, 1997). Empowerment means having personal power and freedom with certain limitations to use that power. People who can not afford do not have a feeling of personal power nor have permission to use this power either (Abdoli, 2008).

\section{Research Method}

The aim of this research was to test the hypothesis that explains the influence, the nature and the form of interaction between spiritual intelligence variable $(X)$ and employees' empowerment variable $(Y)$. The statistics method that was used is inferential statistics. It is the technique of statistics that is used to analyze the sample data and the results are applied to the population (Sugiyono, 2008).

This type of this research is descriptive verification research because it describes the research variables and studies the relation of the variables from the hypotheses have been made systematically through statistical testing. (Sugiyono, 2008). Whereas the method that was used is a survey research method, this is according to the opinion of Sugiyono (2008) which states that survey research is a research which is conducted on large and small populations, but the data which is studied is the data from the samples that are taken from the population, so that it is found the relative events, the distribution and the relation between sociological and psychological variables.

The unit of analysis in this study is that individual employees of PT.CMK. A population of 130 people is using a sample withdrawal slovin in order to obtain a sample of 57 people with simple random sampling technique. The method of data collection is the primary data source with the research instrument using a questionnaire.

This study consisted of two variables: spiritual intelligence as an independent variable and the empowerment of employees as the dependent variable.

The statistical hypothesis in this research is as follows:

$\mathrm{Ho}: \beta=0$ spiritual intelligence has no effect on empowerment

$\mathrm{H} 1: \beta \neq 0$ intelligence spiritual influences on empowerment

Data collection techniques are using validity and reliability test, descriptive analysis test, simple regression analysis and t test.

\section{The Result of Analysis and Discussion}

\subsection{Descriptive Analysis}

Descriptive analysis is an analysis which is based on the results of the answers that are obtained from respondents. In this research, descriptive analysis was conducted to determine public perceptions of respondents about variables of spiritual intelligence $(X)$ and empowerment $(Y)$. To get view of these variables, the score of respondents will be analyzed descriptively.

Descriptive analysis in this study shows that for the spiritual intelligence of employees at the company which was 
studied had high spiritual intelligence. Likewise for empowerment variable which was done by the company is included in the high criteria as well.

\subsection{Verification Analysis}

\subsubsection{Simple Regression Results}

Based on calculations using the SPSS 19.0 program, it can be seen a simple regression equation as follows:

$$
Y=18.238+0.903 X
$$

Based on the above equation, the result of the analysis states that:

- If the spiritual intelligence increases one-unit, the empowerment will tend to increase by 0.903 units.

- Constant value of 18238 means if the spiritual intelligence is not implemented or equal to zero (0), the empowerment is 18238 units.

\subsubsection{Determination and Correlation Coefficient}

Based on calculations using the SPSS 19.0 showed the value of $R$ is equal to 0.678 , the correlation coefficient value can be seen that the relation between Spiritual Intelligence $(X)$ with Empowerment $(Y)$ is by 0.678 and included in the strong category with the direction of a positive relation. The direction of a positive relation between the empowerment and spiritual Intelligence shows that good spiritual intelligence tends to be followed by an increase in employee empowerment.

Thus it can be seen that $\mathrm{R}$ Square value of 0.460 means spiritual intelligence give effect of $46 \%$ to the empowerment, while the remainder of $54 \%$ is influenced by other factors which are not addressed in the study.

\subsubsection{Hypothesis Testing}

To test the hypothesis whether it is accepted or rejected, which means to test the effect of independent variables on the dependent variables, the coefficient testing should be conducted using tcount.

Statistical calculation results obtained table value of 1.67 while tcount value of 6.839 . Because tcount (6.839) is larger than table (1.67) then the error rate of $5 \%$ has strong reason to reject $\mathrm{Ho}$ and accepts the research hypothesis (H1), so it can be concluded that spiritual intelligence influences on employee empowerment at PT.CMK.

The result of this study supports the statement of Esmaiil (2014) which states that spiritual intelligence has significant and positive effect on employee empowerment.

\section{Conclusion}

This study was conducted to observe the effect of spiritual intelligence on employee empowerment.

Based on the descriptive analysis, it showed that the spiritual intelligence which is owned by PT.CMK employees is included in the high category, as well as employee empowerment which is undertaken by the company is included in good category.

Based on verification analysis, it showed that spiritual intelligence has positive and significant effect on employee empowerment. The result means that the more increasing levels of spiritual intelligence is, the better empowerment of employees will be.

\section{References}

Abdoli, K. K., and Sheihki, Z. (2013). Investigation of Relationship between Spiritual Intelligence and job erosion.

Amram, J. (2005). Intelligence Beyond IQ: The contribution of emotional and spiritual intelligences to effective business leadership, Institute of Transpersonal Psychology.

Amram, J. (2007, August). The Seven Dimensions of Spiritual Intelligence: An Ecumenical Grounded Theory. In Proceedings of 115th Annual Conference of the American Psychological Association. San Francisco: CA. Retrieved on http://www.yosiamram.net/ papers/.

Biberman, J. and Whitty, M. (1997) A postmodern spiritual future for work. Journal of Organizational Change Management, vol. 10, no. 2, pp. 130-138.

Brown, R.B. (2003), Organizational spirituality: the sceptic's version, Organization, Vol. 10 No. 2, pp. 393-400. 
Eckersley, R, (2000), Spirituality, Progress, Meaning, and Values, Paper Presented 3rd Annual Conference on Spirituality, Leadership, and Management, Ballarat, 4 December

Emmons. R. A. (2000) Is spirituality an intenligence? Motivation, cognition, the psychology of ultimate concern. International journal for the psychology of religion, Vol 10, No. 1, 3-26.

Hoffman, E,( 2002), Psychological Testing At Work, Mc Graw Hill, New York

Kanter, A.(1989). Human Resources Management. Terjemahan Jakarta: PT Brahmana Media.

Kanter, R.M. (1993). Men and Women of the Coorporation (2nd) NewYork: Basic Books.

Kanter, A. (1997). Human Resources Management. Terjemahan. Jakarta: PT Brahmana Media.

Klusta, K.M., Laschinger, H.K.S., dan Keer, MS.( 2004). Staff nurse empowerment and effor reward inbalance, Nursing Leadership, 17 (1)pp. 112-128.p. 6-13.

Luthans, Fred. (1998). Organizational Behavior Elevent edition, Mc Growth-Hill Book co, Singapore.

Mudali, (2002), Quote : How High Is Yous Spiritual Intelligence ? http://www.eng.usf.edu/gopalakr/artcles/spiritual.html, 15 Juni 2005

Muhammad Idrus, (2002), Kecerdasan Spiritual Mahasiswa Yogyakarta, Psikologi Phronesis, Jurnal IImiah dan Terapan, Vo.4, No.8, Desember 2002

Momtaz,K.Esmaiil and Roozbahani,T.Mohammad. (2014) An investigating the effect of spiritual intelligence on employees empowerment, Vol.3,No.7.

Nasel, Dagmar Dasha. (2004). Spiritual orientation in relation to spiritual intelligence: A new consideration of traditional Christianity and New Age/individualistic spirituality. Doctoral Dissertation, University of South Australia: Australia.

Nilmawati. (2003). Mencapai Kesuksesan Organisasi Melalui Pemberdayaan. Jurnal Ekobis. Vol. 4. No. 2.

Ningky Munir,(2000), Spiritualitas dan Kinerja, Majalah Manajemen, Vol.124, Juli 2000

Noble K D, (2001)Riding the windhorse: Spiritual Intelligence and the Growth of the Self. Cresskill, NJ : Hampton Press, Inc.

Robbins, S.L.(1996). Perilaku Organisasi: Konsep, Kontroversi dan Aplikasi. Alih Bahasa Hadyana Pujaatmaja. Edisi Bahasa Indonesia, Jilid I. Jakarta: PT Prehalindo.

Robbins, Stephen P. (2006). Perilaku Organisasi. Edisi Bahasa Indonesia. Jakarta : PTI Indeks.

Romie, F.L. (2006). Influence On Employee Preference for Empowerment Practice the "Idean Manager" in Chine. International Journal of Intercultural Relations 31 (207)pp. 87-110.

Sadarusman, Eka. (2004). Pemberdayaan: Sebuah Usaha Memotivasi Karyawan, Fokus Ekonomi, Vol. 3, No.2.

Selman, V., Selman, R.C., Selman, J. and Selman, E. (2005). Spiritual-Intelligence / Quotient, College Teaching Methods \& Styles Journal, 1, 3: 23-30.

Sugiyono,2008.Metodology Penelitian Bisnis. CV Alfabeta Bandung

Thomas, K. W., Velthouse, B. A. (1990). Cognitive Elements of Empowerment : an Interpretative Model of Intric Task Motivation. Academy of Management Review. Vo. 15 No. 4 pp. 666- 681.

Vaughan, F. (2003). What is Spiritual Intelligence?, Journal of Humanistic Psychology, 42, 2: 16-33.

Wiersma, M.L, (2002), The Influence of Spiritual "Meaning-Making" On Career Behaviour, Journal of Management Development, Vo.21, No.7, pp.497-520

Wigglesworth, C. (2004), "Spiritual intelligence: why it matters", Kosmos Journal, spring/ summer , available at: www.kosmosjournal.org Zohar, D., \& Marshall, I. (2000). SQ: Connecting with our spiritual intelligence. New York, NY: Bloomsbury.

Zohar, (2001), The Ultimate Intelligence, Mizam Media Utama, Bandung

Zohar, D., \& Marshall, I. (2004). Spiritual capital: Wealth we can live. San Francisco: Berrett-Koehler. 